\title{
NEW BOOKS AND OTHER PUBLICATIONS RECEIVED
}

\section{BOOKS}

The Chinese Economic Reforms. Stephen Feuchtwang and Athar Hussain, editors. New York: St. Martin's Press, December 1982, \$32.50.

Crisis in the East European Economy. Jan Drewnowski, editor. New York: St. Martin's Press, December 1982, \$22.50.

Economic Growth in Prewar Japan. Takafusa Nakamura. Translated by Robert A. Feldman. New Haven, CT: Yale University Press, January 1983, \$35.

The Economics of the Euro-Market: History, Theory and Policy. R. B. Johnston. New York: St. Martin's Press, December 1982, \$27.50.

Employment Policies in the Soviet Union and Eastern Europe. Edited by Jan Adam. New York: December 1982, \$27.50.

The Export-Import Bank at Work. Jordan Jan Hillman. Westport, CT: Greenwood Press, November 1982, $\$ 35$.

Failed Multinational Ventures. Leon Grunberg. Lexington, MA: Lexington Books, D. C. Heath \& Co., 1981, $\$ 24.95$.

Financial Institutions and Markets in the Far East. Michael T. Skully. New York: St. Martin's Press, October 1982, \$27.50.

The Foreign Corrupt Practices Act (Anatomy of a Statute). George C. Geanias and Duane Windsor. Lexington, MA: Lexington Books, D. C. Heath \& Co., December 1982 , \$23.95.

International Business and Global Technology. J. Davidson Frame. Lexington, MA: Lexington Books, D. C. Heath \& Co., January 1983, \$24.95.

International Marketing (Third Edition). Vern Terpstra. New York: Dryden Press, January 1983.

New Theories of the Multinational Enterprise. Alan Rugman, editor. New York: St. Martin's Press, December 1982, \$27.50.

The Rise and Fall of Freddie Laker. Howard Barnes. New York: Harper \& Row, October 1982, \$14.95 (cloth), \$6.95 (paper).

Risk Trends of U.S. Multinational and Domestic Firms. Mehmet Yasar Geyikdagi. New York: Praeger, November 1982, \$32.95.

\section{OTHER}

Euromoney Country Risk Studies: Turkey, the Problems of Transition. Frost \& Sullivan, Inc. and Wharton Econometrics Forecasting Associates. Bath, UK: The Pitman Press, October 1982, \$145.

Financial Analysis and Planning: Theory and Application. Cheng F. Lee. Reading, MA: Addison-Wesley, January 1983. 